\title{
Retraction
}

\section{Retraction to: High-mobility group A1 protein inhibits p53-mediated intrinsic apoptosis by interacting with Bcl-2 at mitochondria}

\author{
F Esposito, M Tornincasa, A Federico, G Chiappetta, GM Pierantoni and A Fusco
}

Cell Death and Disease (2014) 5, e1206; doi:10.1038/cddis.2014.163; published online 1 May 2014

Retraction to: Cell Death and Disease (2012) 3, e383; doi:10.1038/cddis.2012.126; published online 30 August 2012

The Editorial Board of Cell Death and Disease is retracting the above article (PMID 22932725).

A reader contacted the Editors about apparent duplications in Figures $1 \mathrm{~b}$ and 2c, and possible splicing of an image in Figure 3c. Concerns were subsequently raised about the similarity of the tubulin loading controls in Figure $1 \mathrm{~b}$ to those that appeared in Figure 1c of Cell Death and Differentiation 2006; 13: 1554-63 (PMID 16341121), a paper that was retracted by the authors on 6 December 2013.

Because the Authors were unable to provide the original source files that were used to generate the figures in question, the Editorial Board is retracting this publication. 